\title{
Marka Farkındalığı İle Satın Alma Niyeti Arasındaki İlişki Bağlamında Televizyon Dizilerinde Ürün Yerleştirme
}

\section{Dr. Öner Başarır ${ }^{*}$}

Gelis tarihi: 19.05 .2020

Kabul tarihi: 02.07.2020

\section{Atıf bilgisi:}

IBAD Sosyal Bilimler Dergisi

Sayı: $8 \quad$ Sayfa: $383-403$

Yıl: 2020 Dönem: Güz

This article was checked by Turnitin.

Similarity Index 14\%

Bu makalede araştırma ve yayın etiğine uyulmuştur.

${ }^{1}$ Marmara Üniversitesi, Türkiye, onerbasarir@hotmail.com,

ORCID ID 0000-0003-4437-9481

\section{ÖZ}

Günümüzde, markalar rekabette bir adım öne geçmek adına gelenekselin dışında pazarlama stratejileri uygulamaktadır. Yaratıcı boyutlarıyla dikkat çeken ürün yerleştirme uygulamaları da bu stratejilerden biri olarak öne çıkmaktadır. Ürün yerlestirme; sinema, televizyon ve benzeri mecralarda markalı bir ürünün kendisinin veya ürüne yönelik reklam içeriğinin bulunması, stüdyo ortamlarında markası olan bir ürünün gözle görülür bir şekilde konumlandırılması gibi yollarla, reklam olduğu vurgulanmadan ürünün reklamının yapılması olarak tanımlanmaktadır Bu çalışmada amaç; televizyon dizilerindeki ürün yerleştirme uygulamalarının, marka farkındalığı ve satın alma niyeti ile ilişkisini tespit etmektir. $\mathrm{Bu}$ amaca yönelik olarak, bir anket çalışması yapılmış ve katılımcıların, ürün yerleştirme ile ilgili tutumları ölçülmeye çalışılmıştır. Akabinde, bu tutumların marka farkındalığına ve satın alma niyetine etkisi değerlendirilmiştir. Araştırmanın sonucunda, ürün yerleştirme uygulamalarının marka farkındalığı yaratmaya yardımcı olduğu ve marka farkındalığının da satın alma niyetinde etkisinin söz konusu olduğu tespit edilmiştir.

Anahtar Kelimeler: Ürün yerleştirme, marka farkındalığı, farkındalık, satın alma niyeti, tv dizileri.

\footnotetext{
* Sorumlu yazar
} 


\title{
Product Placement in TV Series in the Context of the Relation Between Brand Awareness
} and Purchase Intention

\author{
Dr. Öner Başarır ${ }^{1 *}$
}

First received: 19.05 .2020

Accepted: 02.07.2020

\section{Citation:}

IBAD Journal of Social Sciences

Issue: $8 \quad$ Pages: 383-403

Year: $2020 \quad$ Session: Fall

This article was checked by Turnitin. Similarity Index 14\%

\author{
${ }^{1}$ Marmara University, \\ Turkey,
} onerbasarir@hotmail.com,

ORCID ID 0000-0003-4437-9481

\begin{abstract}
Today, companies have turned on traditional marketing practices to take a step ahead of the brands they are in competition with. Product placement is on of these practices, which are located in a way that makes the consumer less uncomfortable and which is more remarkable with their creativity levels. It is possible to define product placement as positioning of a branded product in a film, series, theater, computer game and similar content without advertising emphasis. In 1930s, product placement practices have entered our lives with cinema films and than it has started to be applied in many different media like television, theater, novels, digital games, internet environment, video clips and concerts. The purpose of this study is to measure the effect level of product placement in television series on brand awareness and purchasing intention, and also to determine the effect level of brand awareness on purchasing intention. For this purpose, a questionnaire was applied and the attitudes of the participants towards product placement were tried to be measured. After that, the effects of these attitudes on brand awareness and purchase intention were analyzed. As a result of the research, it has been determined that product placement practices help to create brand awareness. And brand awareness has also been found to have an effect on purchasing intention.
\end{abstract}

Keywords: Product placement, brand awareness, awareness, purchasing intention, tv series.

\footnotetext{
* Corresponding author
} 


\section{GİRIŞ}

İlk kabul gördüğü dönemlerden bugüne kadar büyük bir evrim geçiren pazarlama bilimi artık tüketiciyi odak noktasinda tutan ve bunu yaparken de toplumsal hassasiyetleri dikkate alan bir disiplin haline gelmiştir. Bu gelişim sürecinde, tüketiciyi ikna etmek adına pazarlama çalışmalarına ayrılan bütçeler ciddi bir noktaya ulaşmıştır. Bütçelerin artması da beraberinde pazarlama yöntemlerinde çeşitliliğe gidebilme firsatı sunmuştur. Günümüzde, markalarına yönelik farkındalık yaratmak isteyen pazarlama uzmanları da, aynı doğrultuda geleneksel pazarlama yöntemlerinin yoğun rekabet ortamında yeterli olmadığı gerçeğini görmüşlerdir. Bu sebeple firmalar rekabet içinde oldukları diğer markaların karşısına tüketiciye daha yaratıcı şekilde sunulan, geleneksel olmayan reklam mesajları ile çıkmaktadır. Markaların, geleneksel yöntemlerle etkisi altına alamadığ tüketicileri yakalamanın yollarından birisi de ürün yerleştirme uygulamalarıdır. Ürün yerleştirme; sinema, televizyon ve benzeri mecralarda markalı bir ürünün kendisinin veya ürüne yönelik reklam içeriğinin bulunması, stüdyo ortamlarında markası olan bir ürünün gözle görülür bir şekilde konumlandırılması gibi yollarla, reklam olduğu vurgulanmadan ürünün reklamının yapılması olarak tanımlanmaktadır (Gürel ve Alem, 2014, s.5). Ürün yerleştirme kavramının kullanımının geçmişi Türkiye için oldukça yenidir. 2000'li yıllardan sonra Türk filmlerinde karşılaşmaya başladığımız bu uygulamaların televizyon dizilerimizle tanışması ise 2011 yılındaki hukuki düzenleme sonrasına denk gelmektedir.

Marka farkındalığı ise markalama sürecinde bir başlangıç noktasıdır ve süreçteki diğer bileşenlerle güçlü bir bağa sahiptir. Tüketici zihninde marka tarafından oluşturulan etki farkındalık olarak adlandırılmaktadır ve bu durum markaya yönelik görüşlerin ve algıların oluşması için bir ön koşul olarak değerlendirilmektedir. Bu bağlamda pazarlama stratejileri de öncelikle marka farkındalığını sağlamaya yöneliktir. $\mathrm{Bu}$ pazarlama stratejilerinden birisi olan ürün yerleştirme uygulamaları da markaların farkındalık yaratmak için kullandıkları etkin yöntemlerden biri olarak öne çıkmaktadır. Bu uygulamalar, farkındalık yaratmanın yanı sıra rekabet içinde olunan markalardan farklılaşmak adına da faydalı olmaktadırlar. Ürün yerleştirme uygulamaları yenilikçi bir yaklaşımdır ve tüketicilerin zihninde yer etmek isteyen markalar için iyi bir alternatif olarak görünmektedir. Yenilikçi olması ve farklılaşmaya fayda sağlamasının yanında ürün yerleştirme uygulamaları, ekonomik olarak da işletmelere artı değer sağlamaktadır. Bir ürünün tüm özelliklerini ve faydalarını, geleneksel reklam yöntemleriyle anlatabilmek çok da mümkün değildir. Ürün yerleştirme gibi uygulamalarda ise istenildiği takdirde ürüne yönelik çok daha detaylı aktarımlar yapılabilmektedir. Bu sayede hem işletmeler daha düşük birim maliyetlerle daha detaylı bilgilendirme yapabilmekte, hem de tüketiciler ürüne yönelik çok daha hızlı ve yeterli bilgiye sahip olup satın alma karar sürecini hızlandırabilmektedir. İkna sürelerini kısaltan, erişim maliyetlerini düşüren, farklılaşma sağlayan ve tüketiciyi satın almaya yönlendiren bu tarz uygulamaların genel ekonomiye katkısı da kaçınılmazdır. Ürün yerleştirme uygulamaları, marka ve gerçek yaşam arasında bir bağ kurma görevini de üstlenir. Geleneksel reklam uygulamalarına nazaran çok daha gerçekçi uygulandıkları için hangi mecrada maruz kalınırsa kalınsın, tüketicide daha samimi duygular yaratabilmektedir.

$\mathrm{Bu}$ çalışmanın amacı; televizyon dizilerinde yer alan ürün yerleştirme uygulamalarının, marka farkındalığı oluşturmadaki etkisini ölçmek, ayrıca marka farkındalığının satın alma niyetine etkisini tespit etmektir. Bu bağlamda ürün yerleştirme ölçeğine ilişkin alt faktörler olan etik, reklama tepki ve ilgi durumu gibi kavramların, markalama sürecinin temel taşlarından biri olan marka farkındalığına etkisi ayrıca değerlendirilecektir.

\section{KURAMSAL ARKA PLAN}

Ürün yerleştirmeyi, marka farkındalığının satın alma niyetine etkisi bağlamında inceleyen bu çalışmada; Kapferer (1992), Aaker (2009), Tosun (2017), Erdil ve Uzun (2009) gibi çalışmalardan faydalanılarak marka farkındalığı ve Taşkın (2003), Yücel ve Çizel (2018), Odabaşı ve Barış (2002), Isaksson ve Xavier (2009) gibi çalışmalardan faydalanılarak satın alma niyeti kavramı incelenmiştir. Son olarak; Eagle ve Dahl (2018), Zeren ve Paylar (2014), Chan (2012), Tiğlı (2004) gibi çalışmaların da yardımıyla ürün yerleştirme kavramı değerlendirilmiştir. 


\section{Marka Farkındalığı Kavramı ve Farkındalık Piramidi}

Marka farkındalığı, markanın önem derecesinin farkına varmış olan ve markanın ifade etmekte olduğu vaadin bilincindeki insanları belirtir. Marka farkındalığı, tüketicilerin markayı tanıma ve hatırlama sürecidir ve tüketicilerin satın alma kararında olumlu bir etkiye sahiptir (Molinillo, Japutra, Nguyen ve Chen, 2017, s. 169). Markayı tanıma, markanın belli belirsiz tanındığı bir duygu durumundan, muadili olmayan eşsiz bir ürün olduğu inanışına kadar seyreden bir aralıkta değerlendirilebilir. Marka hatırlama ise, tüketiciye markaya dair bir ipucu sunulduğunda marka ile ilgili sahip olduğu önceki bilgileri de değerlendirerek markayı hatırlama becerisi olarak tanımlanabilir (Erbaş, 2018, s.1081). Marka farkındalığı, D. Aaaker'in tüketiciyi merkeze alan marka denkliği değerlendirmesindeki aşamalardan biri olarak öne çıkmaktadır. Tüketicinin zihninde bir markanın çağrıştırdığı değerlerin bütünü ise marka denkliğini açıklamaktadır. Farkındalık da marka denkliğini oluşturan öğelerden bir tanesidir. Son olarak marka farkındalığı ise herhangi bir ürüne ait markayı, potansiyel bir tüketicinin anımsama ve tanıma seviyesidir (Tı̆̆l1, Pirtini ve Çelik, 2007, s.85).

Şekil 1. Marka Farkındalık Piramidi

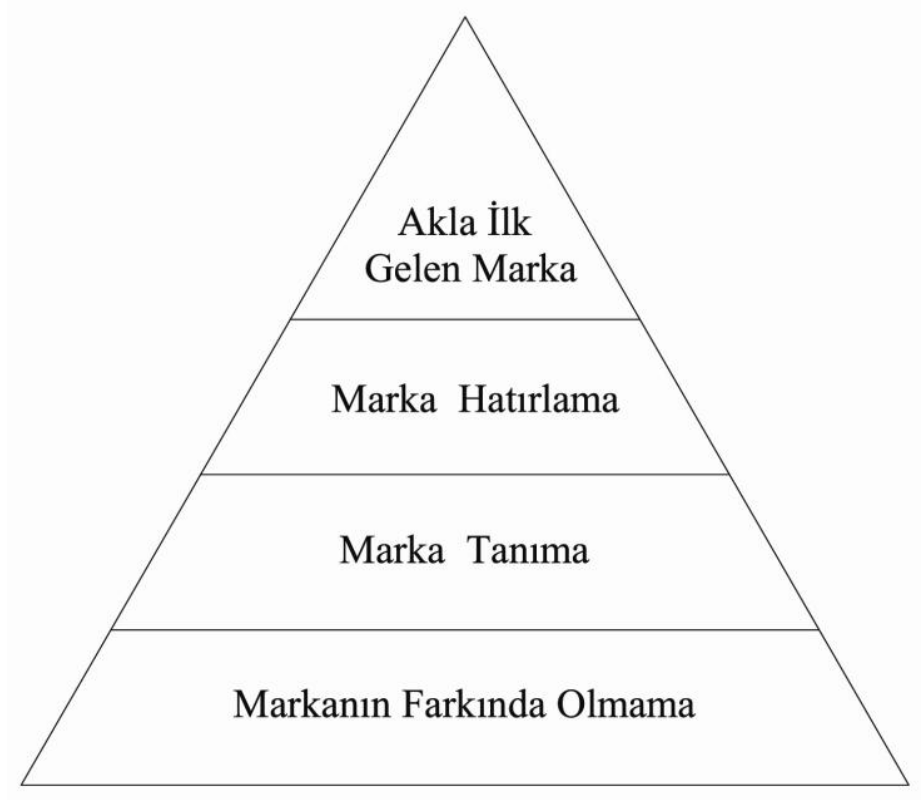

Kaynak: Aaker, D. A. (1991). Managing brand equity: capitalizing on the value of a brand name. 62. New York: The Free Press.

Marka farkındalığının, yukarıda Şekil 1'de de gösterildiği gibi dört aşamalı bir süreci vardır. Bu sürecin ilk aşaması markanın farkında olunmaması iken son aşaması ise ilk akla gelen marka olunmasidir.

Marka tanıma, markaya dair bir ipucu verildiğinde tüketicinin önce markanın ortaya çıkmasını doğrulama yeterliliği olarak tanımlanabilir. (Keller, 2003a, s.66) Markanın tüketicinin zihninde konumlanmasını ya da markayı tüketicinin zihninde konumlandırmak için makul seviyede bilgiye sahip olunmasını da marka tanınırlığı olarak açıklayabiliriz (Macinnis, Shapiro ve Mani, 1999, s.602). En alt seviyede yer alan marka tanıma, yardımlı hatırlama testlerini temel almıştır ve satın alma anında markanın tercih edilmesi yönünden özellikle önemlidir (Aaker, 1991, s.62). Marka tanıma, marka farkındalığının ilk aşaması olarak görülebilir. Satın alma eylemini gerçekleştirme anında tüketicinin seçtiği marka konusunda farkındalık özellikle önemli konumdadır (Erdil ve Uzun, 2009, s.242).

Marka hatırlama ise, ürün kategorisine veya satın alma ya da kullanım durumuna dair bir ipucu verildiğinde tüketicinin hafızasından markayı geri alma yeterliliği olarak tanımlanır (Keller, 2003a, s.66). Marka hatırlama, yardımsız hatırlama testlerini temel almaktadır (Aaker, 1991, s.62). Marka hatırlama bireyin herhangi bir tanıma eyleminden daha kapsamlıdır ve oldukça güçlü bir marka konumuyla alakalidır (Erdil ve Uzun, 2009, s.243). 
Piramidin en üst seviyesinde oldukça özel bir pozisyonda olan akla ilk gelen marka bulunmaktadır. $\mathrm{Bu}$ aşama yardımsız hatırlatma testlerine dayanır. Piramidin bu aşaması çok gerçek bir hisle, markanın öteki markalardan ileride tüketicinin zihninde olmasıdır. Tabi ki zihnin arkasında yakınlarda başka bir marka da olabilir (Aaker, 1991, s.62). Akla ilk gelen marka; insanlar, ürünün kesin kategorisi ile ilişki kurularak markalar üzerine test edildiğinde, markanın zihinden ilk çıkan olup olmadığını ölçer (Kapferer, 1992, s.88).

\section{Satın Alma Niyeti ve Satın Alma Kavramı}

Yeni tüketicilerin nasıl karar verdikleri basit bir soruya benzese de, bireylerin karar verme süreçleri çok uzun yıllardır derinlemesine araştırılan ve üzerinde kafa yorulan önemli konulardan birisidir. Karar veren kişiye, çok seçenekli ve karmaşık durumlarda hangi şekilde seçimi sonlandıracakları konusunda yol gösteren karar verme teorisinde amaçlanan, tüketiciyi tatmin edecek başarılı seçimi yaptırmaktır. Her alternatif açısından doğru fayda ölçümü yapılırsa, en cazip alternatifin hangisi olduğu bulunabilir. Ancak elbette her seferinde seçime yönelik öngörü bu derece kolay olmamaktadır (Yücel ve Çizel, 2018, s.155). Aşağıda da satın alma kavramı ve satın almayı etkileyen faktörler incelenerek, çoğunlukla kolay öngörülemeyen bu seçim sürecinin anlaşılması amaçlanmıştır.

Satın alma kavramı, bazı belirleyici faktörlerin bir birleşimi şeklinde ele alınabilir. Bunlardan ilki satın alma niyeti olarak geçer. Bir diğeri ise, kişisel farklılıklar ve çevre etkileridir (Odabaşı ve Barış, 2002, s.375). Satın alma süreci, tüketicinin bir ihtiyacın farkına varmasının ardından, söz konusu ihtiyacı karşılayıncaya kadar geçen aşamalardır. İnsanlar çoğunlukla ihtiyaçlarını gidermek için satın alma eylemini gerçekleştirirler. İnsanlar mal veya hizmetlerin faydalarını alırlar. Örneğin pamuk gibi bir üründen iplik elde edilirse aynı pamuktan yorgan yapılabilmesi faydası ortadan kalkmış olur. Faydanın ortadan kaldırılması ise tüketimdir. Üretime başlamanın yolu tüketimin gerçekleşmesidir. Her tüketim beraberinde üretimi getirir (Taşkın, 2003, ss.77-78).

Tutum ve davranış ilişkisinin kilit noktası niyet olarak adlandırılabilir. Bu kavram tüketici açısından değerlendrildiğinde, satın alma seçeneklerini gözden geçirme ve alma eyleminin gerçekleşmesi süreçleri arasında cereyan ettiğini söylemek hatalı olmayacaktır (Bergeron, 2004, s.117).

Tüketicinin satın almaya yönelik karar verme aşamasında kayda değer bir rolü olan satın alma niyeti, tüketimin amaçlandığı süreçte bir tüketicinin mal veya hizmeti tercih etme olasılığını tanımlayan varsayım üzerine kurulu bir yapı olarak yorumlanabilir (Isaksson ve Xavier, 2009, ss.23-24).

Tüketicilerin satın alma niyeti; mal, hizmet seçimi, satın alma süreci için harcanan zaman ve bütçeyle ilgili detayların bütünüdür. Pazarlama uzmanları tarafından tüketicide var olan bu niyetin yeterli seviyede anlaşılması, tüketicinin hangi mal veya hizmeti satın alacağını önceden anlamanın yoludur. Buna ek olarak, pazarlama süreci olarak düşünüldüğünde kazanılmış müşteriyi korumanın maliyeti, bir müşteriyi ilk kez kazandırmaktan çok daha azdır ve bu bağlamda satın alma niyetini anlamak kilit rol oynamaktadır (Kozak ve Doğan, 2014, s.65).

Tüketicilerin karar verme süreçleri ise çok uzun yıllardır derinlemesine araştırılan ve üzerinde çalışılan önemli konulardan birisidir. Karar veren kişiye, çok seçenekli ve karmaşık durumlarda hangi şekilde seçimi sonlandıracakları konusunda yol gösteren karar verme teorisinde amaçlanan, tüketiciyi tatmin edecek başarılı seçimi yaptırmaktır. Her alternatif açısından doğru fayda ölçümü yapılırsa, en cazip alternatifin hangisi olduğu bulunabilir. Ancak elbette her seferinde seçime yönelik öngörü bu derece kolay olmamaktadır (Yücel ve Çizel, 2018, s. 155). Satın alma süreci, tüketicinin bir ihtiyacın farkına varmasının ardından, söz konusu ihtiyacı karşılayıncaya kadar geçen aşamalardır. Tüketicinin satın alma karar alma sürecinde önemli bir role sahip olan satın alma niyeti, tüketimin amaçlandığı süreçte bir tüketicinin mal veya hizmeti tercih etme olasılığını tanımlayan varsayım üzerine kurulu bir yapı olarak yorumlanabilir (Isaksson ve Xavier, 2009, ss. 23-24).

\section{Ürün Yerleştirme, Marka Farkındalığı ve Satın Alma Niyeti İlişsisi}

Ürün yerleştirme olarak adlandırılan faaliyet bazıları için gizlenmiş reklam veya sponsorluk bazıları için ise bir illüzyon tekniğidir (Bak ve Eşidir, 2018, s.1160). Ürün yerleştirme; sinema, televizyon ve benzeri mecralarda markalı bir ürünün kendisinin veya ürüne yönelik reklam içeriğinin bulunması, stüdyo ortamlarında markası olan bir ürünün gözle görülür bir şekilde konumlandırılması gibi yollarla, 
reklam olduğu vurgulanmadan ürünün reklamının yapılması olarak tanımlanmaktadır (Gürel ve Alem, 2014, s.5).

Ürün yerleştirme temelde bir reklam türüdür ama geleneksel reklamlarla arasında belirgin farklılıklar söz konusudur. Ürün yerleştirme uygulamalarının ikna etmeye yönelik amacı, genellikle geleneksel reklamlara göre daha az belirgindir (Chan, Lowe ve Petrovici, 2016, s.355). Ürün yerleştirme uygulamaları, tüketicilerin programların akışına dalmış halde kalmasına izin verir ve bunu yaparken incelikler, empati benzeri ilham verici duygulara odaklanır. Bu efektler, markayı spesifik mesajları izleyiciyle buluşturmanın bir yolu olarak kullanan yazarlar, yayın direktörleri ve diğer kreatif profesyoneller tarafindan yaratılır (Liang, Hsiao ve Cheng, 2015, s.1213). Özetle ürün yerleştirme, reklam ile eğlenceyi birleştirir ve geleneksel reklamcılığa uygun bir alternatif olarak önerilir (Eagle ve Dahl, 2018, s.605).

Ürün yerleştirme uygulamaları, günümüzde artarak devam eden sayıda mecrada kendisine yer bulmaktadır. Sinema ve televizyon gibi mecralarla başlayan uygulamalar, teknolojinin değişmesine paralel olarak dijital ortamlar başta olmak üzere çok sayıda mecrada karşımıza çıkabilmektedir. Televizyon dizileri, çevrimiçi diziler, sinema, TV programları, konserler, kitap, dergi, tiyatro, diğer basılı yayınlar, internet ortamı, sahneler, klipler özetle günlük hayatımızda karşımıza çıkabilecek hemen hemen tüm mesaj kanalları artık ürün yerleştirmenin uygulama alanları olarak kullanılmaktadır (Zeren ve Paylar, 2014, s. 15). Bunların arasında en çok tercih edilen mecralar ise sinema filmleri, televizyon ve radyo programları olarak sıralanabilir. Son dönemde bilgisayar oyunları ve mobil uygulamalar da ürün yerleştirme uygulamaları için tercih edilir hale gelmiştir (Tığlı, 2004, s. 30).

Tüketiciler özellikle son yıllarda pazarlama uygulamaları ve eğlencenin iç içe geçmesine şahitlik etmektedirler. $\mathrm{Bu}$ iki kavramı ayrıştırmak da giderek zorlaşmaktadır. Çünkü ürün yerleştirme uygulamaları artık sıklıkla karşımıza bir eğlence biçimi olarak çıkmaktadır. Örneğin BMW markası tüm modellerini potansiyel tüketicilere tanıtmak amacıyla, dünyanın en popüler yönetmenlerini 'The Hire' adlı film serisini yapmaya çağırmıştır. Bu kısa filmler elbette her şeyden önce bir eğlence aracıdır ancak çok daha önemli bir şeye daha hizmet etmektedirler; 'Satış' (Chan, 2012, s. 40).

Ürün yerleştirme uygulamalarının, marka farkındalığı yaratmak adına faydalı bir iletişim yöntemi olduğu söylenebilir. Bu farkındalığın satın alma eylemine dönüşmesi ise tüketicinin bu iletişime sürekli ve markaya ilişkin faydayı görebileceği şekilde maruz kalmasıyla mümkün olabilmektedir. Dolayısıyla yapılan ürün yerleştirmenin tüketiciye rahatsızlık vermeyecek ve programın ana temasıyla bütünlük oluşturacak şekilde, birden fazla frekansla ve markanın adını veya faydasını doğru şekilde aktararak sunulması önemli bir noktadır.

Tüketiciler üzerinde oluşturulan olumlu tutumlar sayesinde, onları ikna etmek kolaylaşır, satın alma niyeti oluşturulur ve sonrasında satın alma davranışının gerçekleşmesi sağlanır. Markalar da bu tutumu oluşturabilecek yollardan bir tanesi olan ürün yerleştirme uygulamalarına yönelmeye başlamışlardır. Dolayısıyla son yıllarda marka sahipleri dizilerde, filmlerde ve TV programlarında ürün ya da marka yerleştirmeye yönelik gerçekleştirilen yeni stratejilere yoğun bir ilgi göstermektedir. Ürün yerleştirmenin markaya ilişkin, tutum ve satın alma niyetlerini etkilediği düşünülse de gündelik hayatta bu uygulamaların tüketici davranışlarına etkisini ölçebilmek çok zordur (Altıntaş, Kurtuldu ve Bilgili, 2017, ss. 1009-1010).

Markalar, ürün yerleştirme uygulamalarını markaları için bir duyurum sağlamak adına uygulamaktadırlar. Satın alma niyeti oluşturarak satışları yükseltmesi hedefinin yanında ürün yerleştirme, marka farkındalığı veya tüketici tutumları üzerinde de son derece etkili olmaktadır (Nakiboğlu ve Serin, 2016, s. 137). Ürün yerleştirme uygulamaları izleyicilerin marka tercihleri, satın alma niyetleri, marka hafızaları ve marka alışkanlıkları üzerinde etki yaratmayı amaçlar. Ve ürün yerleştirme uygulamaları içeriklerin içine entegre edildiğinden beri, reklam ve eğlence arasındaki çizgiyi de bulanıklaştırmayı başarmıştır (Naderer, Matthes, Marquart ve Mayrhofer, 2016, s. 237).

Günümüz koşullarında pazarlama bilimindeki kavramların birbirlerinden tamamen bağımsız düşünülmemesi gerekmektedir. Nitekim bütünleşik pazarlama iletişiminin ortaya çıkmasının temel nedeni de budur. $\mathrm{Bu}$ doğrultuda markaya yönelik yapılan her pazarlama çalışmasının birbirini tamamlayıcı nitelikte olması gerekir. Yapılan bu çalışmaların birbirinden bağımsız değerlendirilmeye 
çalışılması sağlıklı sonuçlar alma olasılığını azaltacaktır (Tunçel, 2009, s. 121). Bu sebeple her ürün yerleştirme uygulaması, marka farkındalığına etki etme olasılığına sahiptir. Birincil amaç ne olursa olsun tüketici ürün yerleştirmeye maruz kaldığı anda bir farkındalık yaşayacaktır. Bu farkındalığın uzun vadeye yayılması ise uygulamanın başarısıyla doğru orantılıdır. Başarılı ve uzun vadeli farkındalık yaratan bir ürün yerleştirme uygulamasının da satın alma niyetine etki edeceğini düşünmek çok da yanlış olmaz.

Yukarıdaki bilgiler ışığında, televizyon dizi ve programlarında, sinema filmlerinde, radyoda, tiyatroda, kitaplarda veya diğer mecralarda karşılaşılan ürün yerleştirme uygulamalarının en önemli hedeflerinden birisinin de marka farkındalığı yaratmak olduğu söylenebilir. Yaratılan marka farkındalığı ise gereksinim anında ve hatta gereksinim söz konusu değilken bile satın alma niyetini oluşturma olasılı̆̆ını arttıracaktır. Bu noktada elbette başarı durumu kusursuz değildir. Her ürün yerleştirme uygulaması başarıyla marka farkındalığı yaratacak ve sonrasında satın alma niyetini etkileyecek diye bir kesinlik belirtmek doğru olmaz. Ancak hedeflemesi, zamanlaması ve kreatif çalışmaları doğru organize edilmiş bir ürün yerleştirme uygulamasında da bu sonuçları beklemek çok da gerçek dışı olmayacaktır.

\section{AMAÇ VE YÖNTEM}

Ülkemizde, ürün yerleştirme uygulamaları yasal olarak 2011 yılından beri uygulanmakta olduğu için bu konuyla ilgili Türkçe literatür sınırlı sayıda kalmıştır. Aynı zamanda bu uygulamaların yeniliklere açık olması da güncel kaynak ihtiyacını ayrıca doğurmaktadır. Türkçe kaynak ihtiyacına katkıda bulunmasının yanı sıra ürün yerleştirme stratejilerinin günümüzde marka farkındalığı oluşturma konusunda etkisini ölçmesi ve oluşturulan marka farkındalığının da her markanın nihai amacı olan satın alma niyetine etkisini irdelemesi sebebiyle bu çalışma önem kazanmaktadır. Bu çalışmanın amacı; televizyon dizilerinde yer alan ürün yerleştirme uygulamalarının, marka farkındalığ 1 ve satın alma niyeti oluşturmada etkisinin olup olmadığını belirlemektir. Marka farkındalığının, satın alma niyetine etkisi olup olmadığı da bir diğer önemli amaç olarak öne çıkmaktadır. Bu bağlamda ürün yerleştirme ölçeğine ilişkin alt faktörler olan etik, reklama tepki ve ilgi durumu gibi kavramların, markalama sürecinin temel taşlarından biri olan marka farkındalığına etkisi ayrıca değerlendirilecektir. Ürün yerleştirmenin alt faktörlerinin satın alma niyetine etkisi de bir diğer değerlendirme konusu olarak belirlenmiştir.

Araştırmada elde edilen veriler; AMOS ve SPSS 23.0 istatistik programı aracılığıyla analiz edilmiştir. Ölçeklerin güvenilirlik analizlerine ve açıklayıcı faktör analizlerine bakılarak yapı geçerliliği test edilmiştir. Faktörler tespit edildikten sonra doğrulayıcı faktör analizi uygulanmış ve model uyum değerlerine bakılarak yapısal eşitlik modeli (YEM) oluşturulmuştur. Ürün yerleştirme ve marka konusu ile ilgili yerli ve yabancı yazında yer alan yüksek lisans ve doktora tezleri ile makalelerden faydalanılarak (Çakır ve Kınıt, 2014; Öztürk, 2007; Bozkurt, 2008; Başgöze ve Kazancı, 2014; Cop ve Baş, 2010; Çildir 2012; Akın, 2008; Ünal, 2008; Baş, 2013; Gupta ve Lord, 1998; Brennan, Dubas ve Babin, 1999; Lee ve Faber, 2007; Russell, 2002; Karrh, 1994; d'Astous ve Seguin, 1999) aşağıdaki araştırma soruları oluşturulmuştur. $\mathrm{Bu}$ model yardımıyla da araştırma sorularının geçerliliği değerlendirilmiştir. Marka farkındalığı ile satın alma niyeti arasındaki ilişki bağlamında ürün yerleştirme uygulamalarının etkisini tespit etmek amacıyla oluşturulan araştırma soruları şu şekildedir;

Araştırma Sorusu 1: Etik değerler, marka farkındalığını doğrudan ve anlamlı bir şekilde etkilemekte midir?

Araştırma Sorusu 2: Reklama tepki, marka farkındalığını doğrudan ve anlamlı bir şekilde etkilemekte midir?

Araştırma Sorusu 3: İlgi durumu, marka farkındalığını doğrudan ve anlamlı bir şekilde etkilemekte midir?

Araştırma Sorusu 4: Etik değerler, satın alma niyetini doğrudan ve anlamlı bir şekilde etkilemekte midir?

Araştırma Sorusu 5: Reklama tepki, satın alma niyetini doğrudan ve anlamlı bir şekilde etkilemekte midir?

Araştırma Sorusu 6: İlgi durumu, satın alma niyetini doğrudan ve anlamlı bir şekilde etkilemekte midir? 
Araştırma Sorusu 7: Marka farkındalığı, satın alma niyetini doğrudan ve anlamlı bir şekilde etkilemekte midir?

\section{Şekil 2. Araştırma Modeli}

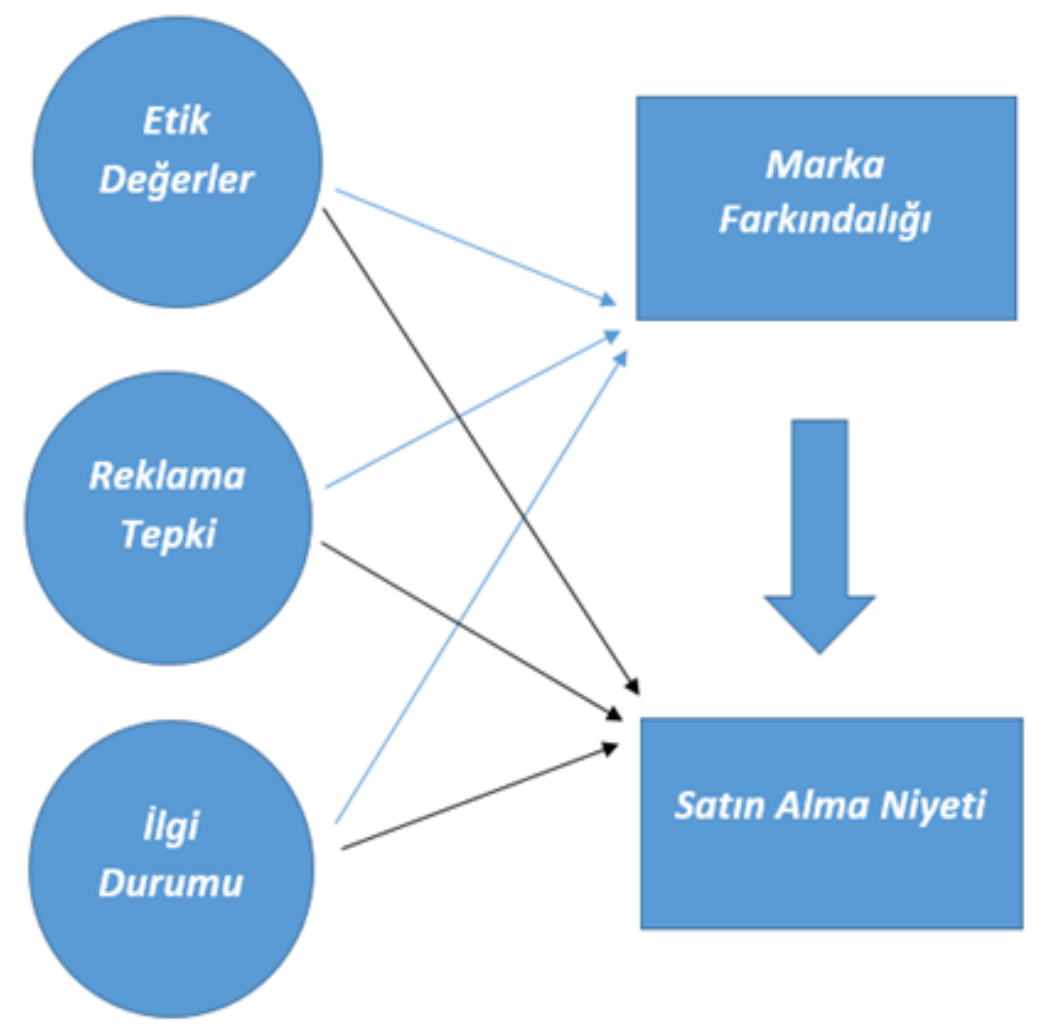

$\mathrm{Bu}$ araştırmanın evreni Türkiye'deki televizyon izleyicileridir. Şu anda resmi ölçüm şirketi TNS tarafindan bu rakam 56.000.000 kişi olarak alınmıştır. Örnekleme yöntemi olarak kolayda örnekleme metodu seçilmiştir ve online anket uygulaması yapılmıştır. Online anket uygulaması sonrasında 416 adet anket uygulanmış ve bu anketlerden 396 adedinin analize uygun olduğuna karar verilmiştir.

$\mathrm{Bu}$ çalışmanın veri toplama yöntemi seçiminde anket yöntemi uygulanmasına karar verilmiştir. Bunun gerekçesi yeterli sayıda tüketiciden veri toplamanın amaçlanmasıdır (Baş, 2005, s. 11). Anket formu hazırlanırken soruların cevaplayıcıları sıkmayacak şekilde ve anlaşılır olmasına özen gösterilmiştir. Anketler çevrimiçi bir anket sitesi (www.surveymonkey.com) aracıllğıyla 18 Aralık 2018 ile 30 Aralık 2018 tarihleri arasında internet üzerinden toplanmıştır.

Anket formu 3 bölümden oluşmaktadır. Birinci bölümde tüketicilerin demografik özelliklerinin belirlenmesi amacıyla oluşturulan sorular bulunmaktadır. İkinci bölümde ise tüketicilerin ürün yerleştirmeye yönelik tutumlarını tespit etmek amacıyla oluşturulmuş 28 ifade ve tüketicilerin satın alma niyetleri ölçmek amacıyla oluşturuşmuş 7 ifade bulunmaktadır. Bu ifadelere katılma dereceleri 5'li likert ölçeğiyle (1=kesinlikle katılmıyorum, 5=kesinlikle katılıyorum) ölçülmüştür. Anketin üçüncü bölümünde ise televizyon izleme alışkanlıklarını ölçmek ve televizyonda karşılaşılan markaları tespit etmek amaciyla oluşturulmuş sorular bulunmaktadır.

Ürün yerleştirme yöntemleri farklı akademisyenler tarafından farklı şekillerde sınıflandırılmıştır. Literatürde en yayın olarak kullanılan ürün yerleştirme üç temel stratejiden oluşmaktadır. Bunlar görsel yerleştirme, işitsel yerleştirme ve hem işitsel hem de görsel yerleştirme stratejileridir. Bu araştırmada araştırma modeli oluşturulurken Gupta ve Lord'un (1998) yapmış olduğu sınıflandırma ele alınmıştır.

Anket formu oluşturulurken, ürün yerleştirmeye ilişkin tutumları ölçmek için Gupta ve Gould (1997) ile Lee, Sung ve Gregorio (2011)'nun çalışmalarındaki ölçekten faydalanılmıştır. Araştırmacı bu bölümde birkaç ifadede değişikliğe gitmiştir. Araştırmada satın alma niyeti ölçeği olarak ise Balakrishnan, Shuaib, Dousin ve Permarupan (2012) tarafından hazırlanan çalışma ile Akgül (2013)'ün çalışmasından, ayrıca 
Karrh, Frith ve Callison (2001)'ın çalışmasındaki ölçek ile Gupta ve Lord (1998) tarafindan sinıflandırılan ürün yerleştirme stratejilerinden faydalanılmıştır.

\section{BULGULAR}

Araştırmaya katılan tüketicilerin demografik özelliklerini tespit etmek amacıyla cinsiyetleri, yaşları, öğrenim durumları, gelir düzeyleri ve meslek gruplarına yönelik sorular oluşturulmuştur. Ankete katılan tüketicilerin büyük bir bölümünün (\%61.4) kadın olduğu tespit edilmiştir. Katılımcıların yaşlarına bakıldığında ise \%47 gibi yüksek bir oranla 32-38 yaș grubunun öne çıktığı gözlemlenmektedir. Bunu $\% 20.7$ oranla 25-31 yaş aralığı takip etmektedir. Sonuçlar eğitim düzeyi açısından incelendiğinde \%60.9 gibi yüksek bir oranla lisans mezunları ön plana çıkmaktadır. Lisans mezunlarını \%21.7 oranlar yüksek lisans mezunları takip etmektedir. Ankete katılan tüketicilerin gelir düzeylerine bakıldığında hem 4.000 TL ile 5.999 TL arası hem de 8.000 TL ve üzerinin aynı oranda (\%27.5) çıktığı gözlemlenmiştir. Son olarak katılımcıların meslek grupları incelendiğinde ise çok yüksek bir oranla (\%61.1) özel sektör çalışanları öne çıkmaktadır.

Çalışmaya yönelik hazırlanan anket içeriğinde 28 ifadeden oluşan bir ürün yerleştirme ölçeği ve 7 ifadeden oluşan bir satın alma niyeti ölçeği mevcuttur. Bu ölçekler üzerinde yapılan açıklayıcı faktör analizleri (EFA) sonrasında ürün yerleștirme ölçeği için 4 adet faktör, satın alma niyeti ölçeği için de tek faktör tespit edilmiştir. 4 faktör üzerinden yapılan doğrulayıcı faktör analizinde (DFA) uyum değerleri (TLI, CFI, RMR) oldukça iyi çıkmıştır. Yapılan analizde CFI değeri 0,952, TLI değeri 0,952, RMR değeri 0,060, GFI değeri 0,925 ve RMSEA değeri 0,51 seviyesinde çıkmıştır ve bu değerler iyi uyuma işaret etmektedir. $\mathrm{Bu} 4$ faktör toplam varyansın \%54,053’ünü açıklamaktadır. Bu faktörler etik değerler, reklama tepki, ilgi durumu ve farkındalık olarak adlandırılmıştır. Satın alma niyeti ölçeğinde tespit edilen tek faktör için yapılan doğrulayıcı faktör analizi (DFA) sonucunda ise NFI, TLI ve CFI değerlerine bakıldığında CFI değeri 0,989 , NFI değeri 0,983 , TLI değeri 0,984 , GFI değeri 0,973 , RMSEA değeri 0,064 ve RMR değerinin de 0,017 olduğu görülmüştür. Özetle faktörün uyum değerleri oldukça iyidir. $\mathrm{Bu}$ faktör toplam varyansın \%70,817'sini açıklamaktadır. Ürün yerleştirme ve satın alma niyeti ölçeklerinin faktör analizi sonrası çıkarılan ifadeler dolayısıyla güvenilirlikleri tekrar ölçülmüş ve güvenilirlik değerinin yükseldiği görülmüştür. Bir başka ifadeyle değişkenleri azaltılmış ölçekler orijinal ölçekler kadar tutarlı bir ölçüm yapabilmekte hatta daha iyi bir güvenilirlik seviyesine sahip görünmektedir. Söz konusu güvenilirlik değerleri (ürün yerleştirme ölçeği 0,874 ; niyet ölçeği 0,929 ) sosyal bilimlere yönelik araştırmalar için oldukça yüksek güvenilirlik düzeyine işaret etmektedir.

Tablo 1. Faktör Analizleri Öncesi ve Sonrası Güvenilirlik Katsayıları

\begin{tabular}{|l|l|l|l|l|}
\hline \multirow{2}{*}{ Ölçekler } & $\begin{array}{l}\text { Faktör Analizi Öncesi } \\
\text { Ölçekler }\end{array}$ & $\begin{array}{l}\text { Faktör Analizi Sonrası } \\
\text { Ölçekler }\end{array}$ \\
\cline { 2 - 5 } İfade Sayısı & Güvenilirlik & İade Sayısı & Güvenilirlik \\
\hline $\begin{array}{l}\text { Ürün } \\
\text { Yerleştirme }\end{array}$ & 28 & 0,825 & 20 & 0,874 \\
\hline $\begin{array}{l}\text { Satın Alma } \\
\text { Niyeti }\end{array}$ & 7 & 0,929 & 7 & 0,929 \\
\hline $\begin{array}{l}\text { Toplam } \\
\text { İfade }\end{array}$ & 35 & 0,886 & 27 & 0,916 \\
\hline
\end{tabular}

Yukarıdaki indekslere dair uyum değerleri ve limitleri Tablo 2'de verilmiştir (Marsh ve Hocevar, 1988; Hu ve Bentler, 1995; Demerouti, 2004; Anderson ve Gerbing, 1984). 
Tablo 2. Yapısal Eşitlik Modeli Uyum İndeksleri ve Limitleri

\begin{tabular}{|l|l|l|}
\hline Uyum Ölçüleri & İyi Düzeyde Uyum & Kabul Edilebilir Uyum \\
\hline X2/df (CMIN/df) & $\leq 3$ & $\leq 4-5$ \\
\hline RMSEA & $\leq 0,05$ & $0,06-0,08$ \\
\hline GFI & $\geq 0,90$ & $0,89-0,85$ \\
\hline AGFI & $0,95-1,00$ & $0,90-0,95$ \\
\hline CFI & $\geq 0,97$ & $\geq 0,95$ \\
\hline IFI & $\geq 0,95$ & $0,94-0,90$ \\
\hline NFI & $\geq 0,95$ & $0,94-0,90$ \\
\hline SRMR & $\leq 0,05$ & $0,06-0,08$ \\
\hline
\end{tabular}

Araştırma kapsamında araştırma sorularının analizine geçmeden önce bir diğer yapılması gereken de yakınsak ve ıraksak geçerlilik analizlerine bakmaktır. Yakınsak geçerliliği tespit etmek için 5 faktörün AVE değerlerine ve birleşik güvenilirlik (CR) seviyesine bakılmıştır. Birleşik güvenilirliğin (CR) 0,70'ten ve AVE değerinden büyük olması ile AVE değerinin de 0,50 'den büyük olması ölçeklerin yakınsak geçerliliğe sahip olduğunu göstermektedir (Fornell ve Larcker, 1981). Analizler sonrası etik değerler, farkındalık, reklama tepki, ilgi durumu ve niyet faktörlerinin tüm AVE değerleri 0,50'nin üzerinde, tüm CR değerleri de 0,70'in üzerindedir. Buna ek olarak tüm CR değerleri de AVE değerinden büyük çıkmıştır. $\mathrm{Bu}$ verilerin ışığında ölçekleri oluşturan tüm faktörlerin yakınsak geçerliliğe sahip olduğu söylenebilir. Iraksak geçerlilik (discriminant validity) analizi için de AVE değerleri ile faktörler arası korelasyon karesi karşılaştırılmıştır. Bütün faktörler için AVE değerlerinin korelasyon karesinden daha yükssek bir değere sahip olduğu görülmüştür. Tüm bu veriler 1şığında, araştırmanın modelinin yapısal geçerliliğe sahip olduğunu ve araştırma sorularının analizize geçmenin uygun olduğunu söylemek mümkündür. Özellikle sosyal bilimlerde yeni bir teori oluşturma ve yapı geçerliliği gibi konularda yüksek potansiyeli olan YEM, bu araştırmada hipotezlerin geçerliliğinin tespitinde kullanılan teknik olmuştur. Araştırmada öncelikle ölçeklerin güvenilirliği tespit edilmiş, açıklayıcı faktör analizi ve doğrulayıcı faktör analizleri yapılarak araştırma üzerine kurulan modelin istatistiksel olarak anlamlı olduğu görülmüş ve örneklemin YEM için yeterli olduğu anlaşılmıştır. 


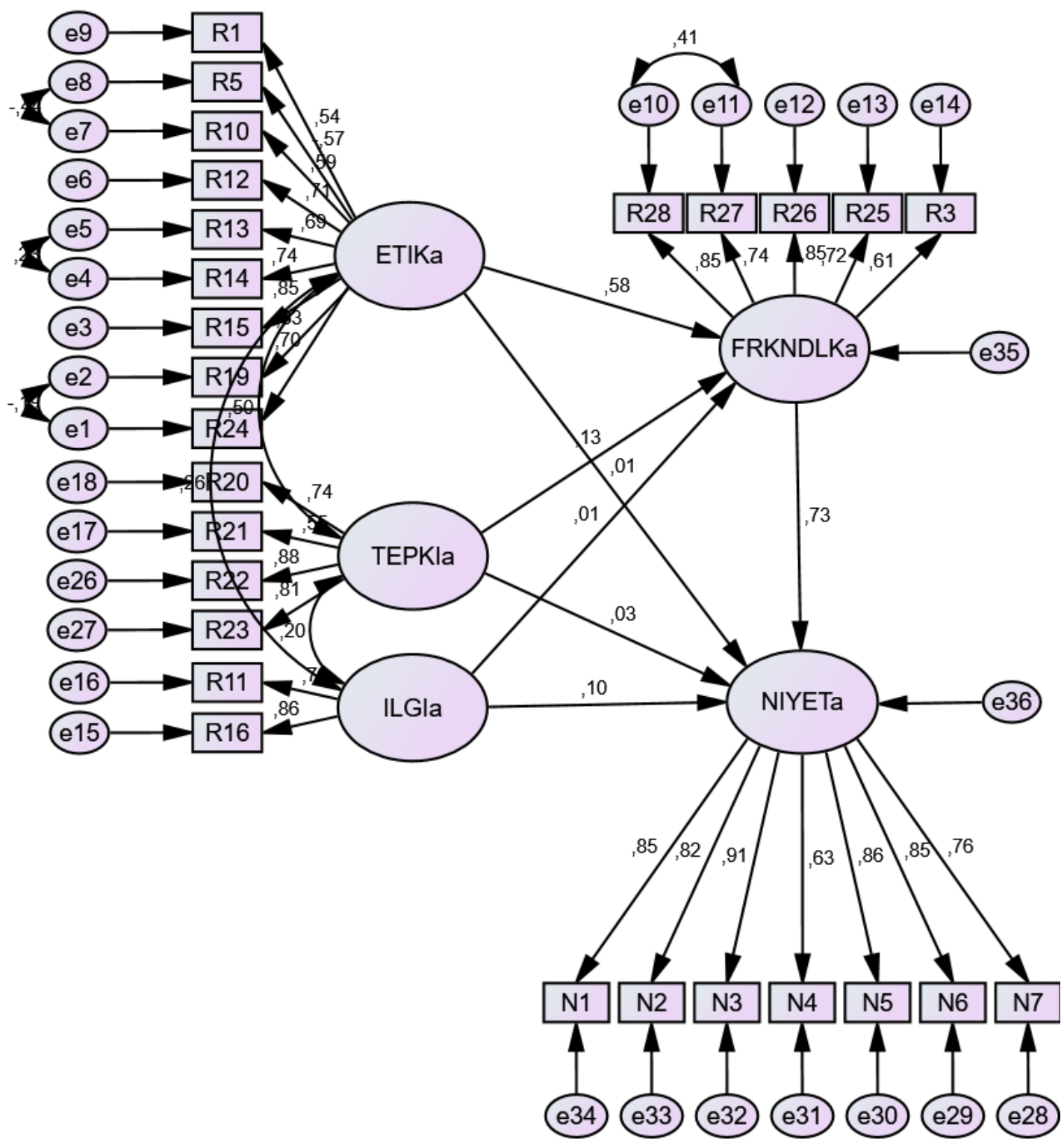

Şekil 3. Yaplsal Eşitlik Modeli ve Parametre Değerleri

Araştırma kapsamında oluşturulan yapısal eşitlik modellemesinde; ürün yerleştirme ölçeğini oluşturan alt faktörlerden etik değerler, reklama tepki ve ilgi durumu faktörlerinin bir diğer alt faktör olan farkındalığa etkisi incelenmiş̧ir. Ayrıca farkındalık alt faktörünün de satın alma niyetine etkisi irdelenmiştir. Bu model tüm parametreleriyle Şekil 3'te gösterilmiştir. Şekil 3'te verilen yapısal eşitlik modeli üzerinden araştırma sorularının analizine geçilmeden önce model uyum değerleri incelenmiştir. Modele yönelik uyum değerleri Tablo 2'de detaylı bir şekilde verilmiştir. Tablo 2'de verilen model uyum değerlerine bakıldığında CMIN/df, RMSEA, IFI, NFI değerlerinin iyi düzeyde uyuma, GFI, CFI ve RMR değerlerinin de kabul edilebilir seviyede uyuma işaret ettiğini söyleyebiliriz. Bu aşamada Tablo 3 'te araştırma modelinde tanımlanan etkileşimlerin analiz bulguları verilmiştir. 
Tablo 3. Değişkenler Arasındaki Etki Durumları

\begin{tabular}{|c|c|c|c|}
\hline Araştırma Modelinde Tanımlanan Etkiler & $\begin{array}{l}\text { c.r. } \\
\text { Değeri }\end{array}$ & p Değeri & $\begin{array}{l}\text { Standart } \\
\text { Doğrudan } \\
\text { Etki }\end{array}$ \\
\hline Farkındalık $\leftarrow$ Etik Değerler & 8,758 & $* * *$ & 0,577 \\
\hline Farkındalık $\leftarrow$ Reklama Tepki & 2,248 & 0,025 & 0,126 \\
\hline Farkındalık $\leftarrow$ İlgi Durumu & 0,203 & 0,839 & 0,010 \\
\hline Niyet $\leftarrow$ Etik Değerler & 0,172 & 0,863 & 0,010 \\
\hline Niyet $\leftarrow$ Reklama Tepki & 0,646 & 0,518 & 0,031 \\
\hline Niyet $\leftarrow$ İlgi Durumu & 2,321 & 0,020 & 0,101 \\
\hline Niyet $\leftarrow$ Farkındalık & 10,629 & $* * *$ & 0,727 \\
\hline
\end{tabular}

Şekil 3 ve Tablo 2'de yer alan bulgular incelendiğinde etik değerler ile farkındalık arasındaki katsayının 0,58 seviyesinde olduğu görülmektedir. Etik değerlerin farkındalık üzerindeki etki seviyesinin orta büyüklükte ve pozitif yönlü olduğu söylenebilir. Ayrıca $t$ değeri de $p<0,01$ önem düzeyinde istatistiksel olarak anlamlıdır. Bu da birinci araştırma sorusunun doğrulandığını göstermektedir. Analiz bulgularına göre reklama tepki ile farkındalık arasındaki katsayının 0,13 seviyelerinde ve pozitif yönlü olduğu gözlemlenmiştir. Ayrıca t değeri de $\mathrm{p}<0,05$ önem düzeyinde istatistiksel olarak anlamlıdır. Bu haliyle, ikinci araştırma sorusu da doğrulanmıştır. Bulgular, ilgi durumu ve farkındalık arasındaki etki açısından incelendiğinde pozitif yönlü ve etki katsayısının 0,010 olduğu bir etki gözlemlenmiştir. Ancak t değeri $\mathrm{p}>0,05$ olduğu için istatistiksel olarak anlamlı bir etki söz konusu değildir. Buna göre, üçüncü araştırma sorusu doğrulanmamıştır. Analiz bulgularına göre etik değerlerin satın alma niyeti üzerindeki etkisinde katsayı pozitif yönlüdür ve 0,010 'dur. Ayrıca t değeri $p>0,05$ olduğu için istatistiksel olarak anlamlı bir etki yoktur. Buna göre dördüncü araştırma sorusu da doğrulanmamıştır. Analiz sonrasında, reklama tepkinin satın alma niyeti üzerindeki etkisine bakıldığında katsayının 0,03 olduğu gözlemlenmiştir. Pozitif yönlü belirlenen etkinin $t$ değeri $p>0,05$ olduğundan istatistiksel olarak anlamlı bir etki yoktur. $\mathrm{Bu}$ durumda, beşinci araştırma sorusu da doğrulanmamıştır. Analiz bulgularına göre, ilgi durumunun satın alma niyeti üzerindeki etkisi pozitif yönlüdür ve katsayısı 0,10 olarak belirlenmiştir. Ayrıca t değeri de $\mathrm{p}<0,05$ önem düzeyinde istatistiksel olarak anlamlıdır. $\mathrm{Bu}$ haliyle, altıncı araştırma sorusu doğrulanmıştır. Son olarak araştırmada öne sürülen yapısal modele göre farkındalığın niyet üzerindeki etkisi incelendiğinde, katsayının 0,73 ve pozitif yönlü olduğu tespit edilmiştir. Ayrıca t değeri $\mathrm{p}<0,01$ önem düzeyinde istatistiksel olarak anlamlıdır. Bu durumda, yedinci araştırma sorusu doğrulanmıştır.

\section{TARTIŞMA VE SONUÇ}

$\mathrm{Bu}$ araştırmanın temel amacı; televizyon dizilerinde yer alan ürün yerleştirme uygulamalarının, marka farkındalığı oluşturmadaki etki seviyesini ölçmek ve ayrıca marka farkındalığının satın alma niyetine etkisini tespit etmektir. Bu bağlamda ürün yerleştirme ölçeğine ilişkin alt faktörler olan etik, reklama tepki ve ilgi durumu gibi kavramların, markalama sürecinin temel taşlarından biri olan marka farkındalığına etkisi ayrıca değerlendirilmiştir. Bu değerlendirme, televizyon dizilerinde yapılmakta olan ürün yerleştirme uygulamalarının yarattığı çağıışımlar üzerinden yapılmıştır. Bahsedilen bu değişkenlere yönelik bulgular, tablolarda sunulmuş ve değişkenler arası etki seviyeleri incelenmiştir. Daha sonra kurulan model üzerinden araştırma soruları değerlendirilmiştir.

\section{Literatür Taraması}

Literatürde, ürün yerleştirme uygulamalarının marka farkındalı̆̆ı, marka tutumu oluşturmasıyla ilgili ve tüketicilerin ürün yerleştirmeye yönelik tutumlarını tespit etmek amacıyla çok sayıda çalışma bulunmaktadır (Keskin ve Kurtuldu, 2017, s.208): Ferguson ve Burkhalter (2015) çalışmalarında, hiphop kültüründe müziğe marka yerleştirmenin etkisini incelemişlerdir. Çalışmaları sonucunda müziğe yerleştirilen markaların tüketicideki marka tutumu üzerinde olumlu etkileri olduğunu tespit etmişlerdir. Homer (2009) çalışmasında, ürün yerleştirmelerde tekrarların üzerinde durmuş ve özellikle aktif ürün yerleştirmelerde frekansın marka tutumunda düşüşe sebep olduğunu görmüştür. Çakır ve Kınıt (2014) araştırmalarında, ürün yerleştirme uygulamalarının sponsorlukla kıyaslandığında marka farkındalığı oluşturmada daha etkili olduğunu, satın alma davranışlarında daha etkin bir rol üstlendiğini, ancak satın alma niyeti oluşturmada da sponsorluğun etkisinin daha çok olduğunu 
gözlemlemişlerdir. Gerçek ve İmik Tanyıldızı (2012) araştırmalarında, marka farkındalığı ve ürün yerleştirme ilişkisini incelemiş ve ürün yerleştirmeyle, marka farkındalığı arasındaki ilişkinin negatif olmadığını görmüşlerdir. Çakır (2011) çalışmasında, ürün yerleştirme uygulamalarının marka bilinirliği ve marka hatırlanırlığı üzerinde pozitif bir etkisi olduğunu görmüștür. Bulut (2014) çalışmasında, dizi izleyicileri üzerinden bir araştırma yapmış ve ürün yerleştirmenin marka bilinirliğine ve satın almaya etkisini incelemiştir. Çalışma sonucunda ürün yerleştirmenin tüketici davranışları üzerinden etkisi olduğu saptanmıştır. Çildir (2012) çalışmasında, ürün yerleştirmenin marka ve satın alma niyetiyle ilişkisini araştırmıştır ve ürün yerleştirme uygulamalarının hatırlanan markalar üzerinden satın alma niyeti yaratmada yetersiz olduğunu görmüştür. Buna ek olarak ürün yerleştirme uygulamalarının marka hatırlanırlığı sağladığını da ayrıca tespit etmiştir. Serin (2014) çalışmasında, üniversite öğrencileri üzerinde bir araştırma yapmış ve ürün yerleştirme ile marka bilinci arasında olumlu bir ilişki bulmuştur. Ancak aynı çalışmanın sonucuna göre ürün yerleştirmeye dair tutumlarla geleceğe yönelik satın alma niyeti arasında bir ilişki tespit edilememiştir. Lin ve Chen (2013) çalışmalarında, çevrimiçi yapılan ürün yerleştirme uygulamalarının satın almaya ilişkin kuvvetli bir niyet oluşturduğunu görmüşlerdir. Hudson ve Elliott (2013) çalışmalarında, ürün yerleştirmenin çocuklar ve ergenler üzerindeki etkisini incelemişler ve çok küçük yaşta çocukların dahi bu uygulamaları algıladıklarını ve etkisi altında kaldıklarını tespit etmişlerdir. Başgöze ve Kazancı (2014) araştırmalarında, televizyon dizilerindeki ürün yerleştirme uygulamalarının tüketiciler nezdinde olumlu tutumlara sebep olduğunu, ürünü satın almaya yönelik eğilimlerin arttığını görmüşlerdir. Reklama karşı tutumların, ürün yerleştirmeye yönelik tutumlar ve satın alma eğilimi ile ürün yerleştirmeye yönelik tutum ile marka imajı arasında aracı bir etkisini olduğunu tespit etmişlerdir. Eyüboğlu (2015) çalışmasında, televizyon dizilerindeki ürün yerleştirmelerin farkındalık yaratma üzerine etkisini incelemiş ve senaryo entegrasyonu ile yapılan aktif ürün yerleştirmelerin farkındalığının, pasif ürün yerleştirme ile yapılan ürün yerleştirmelerin farkındalığından daha anlamlı bir şekilde yüksek olduğunu tespit etmiştir. Ünlü kullanımı ve geleneksel reklamlarla desteklendiğinde de bu yüksek farkındalığın daha da arttı̆̆ sonucuna varmıştır. Sung ve Gregorio (2008) çalışmalarında, ürün yerleştirmeye karşı tutumları çeşitli kitle iletişim araçları bazında incelemiş ve sonuç olarak ürün yerleştirmeye karşı tutumların genel anlamda tüm kitle iletişim araçlarından pozitif olduğunu görmüş fakat şark1, video oyunu gibi ortamlardaki ürün yerleștirmelerin film, dizi gibi ortamlarda yapılanlara göre daha az kabul gördüğünü sonucuna varmışlardır. Toomey ve Francis (2013) araştırmalarında, 8-12 yaş grubundaki çocuklara markalı ürün yerleştirme örnekleri izletmiş ve örneklerde mevcut olmayan markalardan daha fazla tercih edildiklerine ilişkin bir kanıta ulaşamamışlardır. Redker vd. (2013) araştırmalarında, son dönemlerde hem filmlerde hem de dizilerde ürün yerleştirme sayısının çok arttığını tespit etmiş ve ürün yerleştirmenin dizi veya filmdeki uygulama yerinin tüketicilerin nezdinde önemli olduğunu bulgusuna varmışlardır. Alagöz ve Güler (2018) çalışmalarında, ürün yerleştirmeye yönelik tüketici tutumu ile satın alma niyetinin ilişkisini değerlendirmiş ve ürün yerleştirme uygulamalarına yönelik tutumlar ile ürünü satın almanın pozitif yönlü bir ilişkiye sahip olduğunu tespit etmiştir.

Yukarıda bahsedilen çalışmalara ek olarak ürün yerleştirme, marka ve satın alma konuları ile ilgili yerli ve yabancı yazında, birçok başka yüksek lisans ve doktora tezleri ile makaleler yer almaktadır. Nebenzhal ve Secunda (1993) çalışmalarında, 171 üniversite öğrencisine anket uygulaması yapmış ve katılımcıların diğer tutundurma faaliyetlerine göre, aşırıya kaçılmadığı takdirde ürün yerleştirmeyi tercih ettiklerini belirlemiştir. $\mathrm{Bu}$ sonuç, bu çalışmada ortaya çıkan ürün yerleştirme etkileriyle paralellik göstermektedir. Delorme, Reid ve Zimmer (1994) ise 29 üniversite öğrencisiyle bir odak grup çalışması yapmıştır. Bu çalışmada, ürün yerleştirmenin filmlere gerçeklik kattığı ancak aşırıya kaçılmaması gerektiği sonucu çıkmıştır. Ong ve Meri (1994) araştırmalarını 75 kişiye anket uygulayarak gerçekleştirmişlerdir. Araştırmaya göre, ürün yerleştirme ve satın alma niyetine yönelik tutumlar incelenmiş ve katılımcılarda genellikle olumlu tutumlar görülmüştür. $\mathrm{Bu}$ da yine bu çalışmayla paralellik gösteren bir sonuçtur. Karrh (1994) çalışmasında, 76 üniversite öğrencisiyle 5 markaya yönelik deney gerçekleştirmiştir. Katılımcılar ilk sırada ve en çok tekrar edilen markayı daha iyi hatırlamıştır. Daha az bilinen markalarda ürün yerleştirmenin daha etkili olduğu görülmüştür. Vollmers (1995) çalışmasını 140 ilköğretim çağındaki çocuğa deney yaparak gerçekleştirmiştir. Çocukların ürün yerleştirmeden nasıl etkilendikleri incelenmiş ve uygulamanın sunum tarzına göre etkilenmede farklılıklar gözlemlenmiştir. Babin ve Carder (1996) çalışmalarında, 98 üniversite 
öğrencisine anket uygulamıştır. Rocky 3 ve Rocky 5 filmleri katılımcılara izlettirilmiş ve katılımcıların üçte birine yakınının, markaların yarısını hatırladığı görülmüştür. Gupta ve Gould (1997) ise 1012 üniversite ögrencisine anket uygulamıștır. Katılımcılarda ürün yerleştirmeye yönelik olımlu tutum tespit edilmiştir. d'Astous ve Chartier (2000) çalışmalarında, 103 kişiye film izletmiş ve filmi izlettikten 1 hafta sonra telefonla anket uygulamıştır. Katılımcılar, ürün yerleştirme uygulamalarının farkındalıklarına etki ettiğini belirtmişlerdir. Bu sonuç, bu çalışmanın sonuçlarıyla benzer bir sonuçtur. Ürün yerleştirmenin, marka farkındalığına etki ettiği iki çalışmanın ortak yönü olarak göze çarpmaktadır. Russell (2002) ise 107 kişi üzerinde bir deney gerçekleştirmiştir. Bu deneye göre ürün yerleştirme doğal yapılırsa, marka algısında pozitif etkiler yaratmaktadır. Auty ve Lewis (2004) çalışmalarında, 6-12 yaş arası 105 çocuk üzerinde odak grup çalışması yapmıştır. Katılımcılar filmde ürün yerleştirmesi yapılan içeceği içmeyi tercih etmişlerdir. Seçimin tamamen bilinçli olup olmadığı ve yaş durumunun etkisi tespit edilememiştir. Lee ve Faber (2007) çalışmalarında, 155 öğrenciye anket uygulamışlardır. Sonuç olarak, marka hatırlamanın artmasında ürün yerleştirmenin türü ve oyun içeriği arasında bir bağ bulunamamıştır. Jin ve Villegas (2007) ise 185 üniversite öğrencisine anket uygulamışlardır. Bu çalışmada, ürün yerleştirmenin katılımcılarda olumlu tutuma sebep olduğu ve satın alma niyetlerini etkilediği belirlenmiştir. Bu sonuç, bu çalışmadaki bulgularla birebir örtüşmektedir. Yang ve Roskos-Ewoldsen (2007) çalışmalarında, 373 öğrenciye anket uygulamıştır. Sonuçlara göre, ürün bir ünlü tarafından kullanıldığında hatırlama oranı maksimum seviyededir. Ürün yerleştirmesi yapılan markanın hatırlanırlığı yapılmayana göre daha fazladır ve daha çok tercih edilmektedir. Lehu ve Bressoud (2008) ise oldukça ciddi bir kitle üzerinde anket çalışması uygulamıştır. 3532 kişiye yapılan anket sonuçlarına göre, belirgin ve teması olan ürün yerleştirmelerin daha fazla marka hatırlanırlığı sağladığı tespit edilmiştir. Cowley ve Baron (2008) çalışmalarında, 215 üniversite öğrencisine anket uygulamış ve belirgin ürün yerleştirmeler eğer program seviliyorsa negatif, sevilmiyorsa da pozitif marka algısı yaratmaktadır sonucuna ulaşmışlardır. Bozkurt (2008) ise 273 kişi üzerinde anket uygulamıştır. Bu çalışmaya göre, sinema filmlerindeki ürün yerleştirme uygulamalarının marka hatırlamaya etkisi azımsanmayacak seviyede çıkmıştır. Akın (2008) çalışmasında, 460 kişiye anket uygulamıştır. Bu çalışmanın sonucuna göre, reklamı yapılan ürünlerin satın almak için uygunluğu kanaati tüketicide mevcut görülmemektedir. Ancak reklamlar marka bilinci ve değerine olumlu etki etmektedir. Özellikle satın alma etkisine yönelik sonuç değerlendirildiğinde, bu çalışmayla negatif yönlü bir ilişkinin söz konusu olduğu söylenebilir. Birçok bilimsel çalışmada olduğu gibi deneklerin profiline göre, aynı araştırma sorusuna yönelik farklı sonuçlar ortaya çıkabilmektedir. Ünal (2008) ise 100 üniversite öğrencisine anket uygulamıştır. Çalıșmaya göre, marka hatırlanma oranları oldukça düșük seviyede kalmıștır. 4100 marka hatırlama sorusundan 539 tanesi doğru cevaplanabilmiştir. Bu çalışmanın sonucu da tıpkı bir önceki bahsedilen çalışmada olduğu gibi, makalenin sonuçlarıyla negatif yönlü ilişki içerisindedir. Cop ve Baş (2010) çalışmalarında, 400 kişi üzerinden anket uygulaması gerçekleştirmiştir. Çalışmanın sonucuna göre, tüketiciler kendisine kitle iletişim araçlarıyla en iyi şekilde ulaşan markaları tercih etmektedir. Wouters ve Pelsmecker (2011) ise 42 TV içeriğine yönelik içerik analizi gerçekleştirmiştir. Çalışmada, Belçika ve ABD ülkelerinde yapılan ürün yerleştirmeler karşılaştırılmış ve özellikle ABD'deki uygulamaların çok daha profesyonel yapıldığı tespit edilmiştir. Cholinski (2012) çalışmasında, 200 kişiye anket uygulamıştır. Katılımcılara göre ürün yerleştirmeler farkındalığ 1 arttırmaktadır. Ancak marka seçimlerinde pozitif bir etkisi olacağının garantisi yoktur. Farkındalık açısından bakıldı ğında bu sonuç, bu makaledeki bulgularla paralellik göstermektedir. Baş (2013) çalışmasında, 574 kişi üzerinde anket uygulaması gerçekleştirmiştir. Sonuçlara göre, kadınlar erkeklere kıyasla reklamlara daha olumsuz bakmaktadır. Ürün yerleştirmenin gerçeklik algısı oluşturduğu konusunda da olumlu sonuçlar çıkmıştır. Kara (2016) ise 975 kişi üzerinde kapsamlı bir anket uygulaması gerçekleştirmiştir. Sonuç olarak, TV dizilerinde yapılan ürün yerleştirmelerin satın alma niyeti üzerindeki en etkili mecra olduğu tespit edilmiştir. Eğitim seviyesine göre satın alma niyetinde farklılıklar görülmüştür. $\mathrm{Bu}$ çalışmanın sonucu ile makaledeki bulgular arasında yüksek oranda paralellik söz konusudur. İki çalışmanın tarih olarak yakınlığı ve ülkemizde yapılmış olması da önemli birer ortak yöndür.

Literatürdeki çalışmalar bir bütün olarak değerlendirildiğinde; ürün yerleştirme uygulamalarının marka hatırlanırlığı ve marka farkındalığına pozitif etkileri olduğunu söylemek mümkündür. Bazı çalışmalarda söz konusu pozitif etki daha yüksek seviyelerde tespit edilmiş, bazılarında ise etki seviyesi pozitif olmakla beraber, bu etkinin garantisinin olmadığ vurgulanmıştır. Bu çalışmada da 
benzer sonuçlar ortaya konulmuştur. Ürün yerleştirmeye yönelik faktörlerin bazısı marka farkındalığına yüksek seviyede etki ederken, bazısında etki seviyesi görece daha az çıkmıştır. Bir diğer konu ise, literatürdeki çalışmalarda ürün yerleștirme uygulamalarının satın alma niyetine yönelik pozitif etkileri olduğunun tespit edilmiş olmasıdır. Bu çalışmada da bu durum aynı şekildedir. Yerli ve yabancı yazındaki araştırmalarla paralel sonuçlar ortaya koyması, bu çalışmanın tutarlılığını da gözler önüne sermektedir.

Türkiye'de, ürün yerleştirme uygulamaları yasal olarak 2011 yılından beri uygulanmakta olduğu için bu konuyla ilgili Türkçe literatür sınırlı sayıda kalmıştır. Aynı zamanda bu uygulamaların yeniliklere açık olması da güncel kaynak ihtiyacını ayrıca doğurmaktadır. Türkçe kaynak ihtiyacına katkıda bulunmasının yanı sıra ürün yerleştirme stratejilerinin günümüzde marka farkındalığı oluşturma konusunda etkisini ölçmesi ve oluşturulan marka farkındalığının da her markanın nihai amacı olan satın alma niyetine etkisini irdelemesi sebebiyle bu çalışma önem kazanmaktadır. Bu bağlamda ürün yerleştirmenin iletişim kuramlarıyla ilişkisinin incelenmesi sebebiyle bu çalışma, literatüre özgün kaynak kazandırma açısından da önem kazanmaktadır.

$\mathrm{Bu}$ çalışmada ortaya konan modelin yapılan tüm analizler yardımıyla güvenilir ve geçerli olduğu yukarıda da söylenildiği gibi görülmüștür. Model uyum değerleri ve yapısal geçerlilik analizlerinin de çok iyi değerler elde edilmiştir. Analiz sonucunda; 'etik değerler ve farkındalık', 'reklama tepki ve farkındalık', 'farkındalık ve niyet', 'ilgi durumu ve niyet' değișkenleri arasında pozitif yönlü ilișki tespit edilmiştir. Buna karşıllık 'ilgi durumu ve farkındalık', 'etik değerler ve niyet' ve 'reklama tepki ve niyet' değişkenleri arasında da anlamlı etki görülmemiştir.

Araştırma soruları ayrı ayrı ele alındığında şu sonuçlar ortaya çıkmaktadır. İlk olarak birinci araştırma sorusunun desteklendiği görülmüştür. $\mathrm{Bu}$ araştırma sorusunda ürün yerleştirmenin alt faktörlerinden birisi olan etik değerlerin farkındalık üzerinde etkisi olup olmadığı incelenmiştir. Bu iki değişken arasında pozitif yönlü ve yüksek seviyede bir etki söz konusudur. Etik değerler faktörünün ürün yerleştirme ölçeğindeki değişkenleri; ürün yerleştirmenin ahlaki olup olmadığı, yasaklanıp yasaklanmaması gerektiği, hayali markalar mı yoksa gerçek markalar mı olması gerektiği, ücret alınıp alınmaması gibi sorulardan oluşmaktadır. Analiz sonuçlarına bakıldığında bu tür değişkenlerin farkındalık üzerinde etkisi olduğu görülmüştür. Özetle tüketicilerin ürün yerleştirmeyle ilgili etik kaygıları farkındalıklarını da etkilemektedir. Ürün yerleştirmenin ahlaki olduğunu düşünen veya ücret alınmasını normal karşılayan bir tüketicinin, yapılan ürün yerleştirmeyi farketmesi arasında doğrusal bir etki olduğunu söylemek mümkündür.

Araştırmanın ikinci sorusunun da desteklendiği tespit edilmiştir. İkinci araştırma sorusunda yine ürün yerleştirmenin alt faktörlerinden reklama tepkinin, farkındalık üzerindeki etkisi incelenmiştir. Bu iki değişken arasında pozitif yönlü ama düşük seviyeli bir etki olduğu görülmüştür. Reklama tepki faktörünün alt bileşenleri; reklamlar başladığında kanal değiştirmek, reklam izlememek için sinemaya gitmek ve reklama duyulan nefret gibi sorulardan oluşmuştur. Analiz sonuçlarında da görüleceği üzere reklama karşı duyulan nefret veya sempati farkındalık üzerinde etkiye sahiptir. Bu etkinin düşük seviyede olması, ürün yerleştirmenin geleneksel reklam yöntemlerinden farklı olmasına bağlanabilir. Tüketicinin gözünde, ürün yerleştirme eğer senaryo akışında iyi entegre edilirse, reklam algısından uzaklaşmaktadır. Bu da geleneksel reklama karşı tepkili olan kitlenin ürün yerleştirmeye pozitif bakma ihtimalini doğurmaktadır.

Analizler sonucunda üçüncü araştırma sorusu ise desteklenmemiştir. Bu araştırma sorusunda, ürün yerleştirme ölçeğinin alt faktörlerinden ilgi durumunun farkındalık üzerindeki etkisi değerlendirilmiştir. $\mathrm{Bu}$ iki değişkenin birbiri üzerinden doğrudan anlamlı bir etkisi tespit edilememiştir. İlgi durumu faktörü, dizi izleme sıklığı ve dizi izlemeye duyulan sevgiyle ilgili değişkenlerden oluşmaktadır. Buradan da anlaşılacağı üzere, ürün yerleştirmenin uygulandığı dizinin sıklıkla takip ediliyor olunması farkındalık açısından bir anlam ifade etmemektedir. Diziyi izlediği sırada, ürün yerleştirme uygulamasıyla karşılaşan tüketici açısından o diziye duyulan ilgi, farkındalığına pozitif veya negatif bir etkide bulunmamaktadır.

Yapılan analizlere bakıldığında dördüncü araştırma sorusunun da desteklenmediği görülmüş̧ür. $\mathrm{Bu}$ araştırma sorusu, 'etik değerler satın alma niyeti üzerinde istatistiksel olarak anlamlı bir etkiye 
sahiptir' şeklindedir. Önceki araştırma sorularına ve bu araştırma sorusunun sonucuna bakıldığında, etik değerler faktörü farkındalık üzerinde etkilidir ama satın alma niyeti üzerinde doğrudan bir etkiye sahip değildir. Aynı şekilde beşinci araştırma sorusu da desteklenmemiştir ve bu araştırma sorusu reklama tepkinin satın alma niyeti üzerindeki etkisini konu almaktadır. Reklama tepki faktörü de etik değerler faktöründe olduğu gibi farkındalık üzerinde etkilidir ama satın alma niyeti üzerinde doğrudan bir etkiye sahip değildir. Dolayısıyla her iki değişkenin satın alma niyetine doğrudan değil, farkındalık üzerinden dolaylı bir etkisi olduğu söylenebilir.

Analizlere göre altıncı araştırma sorusu da değerlendirilmiş ve bu araştırma sorusu desteklenmiştir. Burada da ilgi durumu faktörünün satın alma niyeti üzerindeki etkisinden bahsedilmektedir. Düşük seviyede de olsa ilgi durumu, satın alma niyeti üzerinde etkin bir rol üstlenmektedir. Buna istinaden yapılabilecek yorum, dizi izleme sıklı̆̆ farkındalığı etkilemese de bu faktörün varlığı satın alma niyeti üzerinde doğrudan bir etkiye sahip görülmektedir.

Yedinci araştırma sorusu ise araştırmanın en önemli araştırma bulgularından birini barındırmaktadır. Yedinci araştırma sorusuna göre farkındalık satın alma niyeti üzerinde etkilidir ve bu soru analizler sonrasında desteklenmiştir. Farkındalık faktörü; görsel, işitsel ve hem görsel hem işitsel ürün yerleştirme uygulamalarıyla ilgili alt bileşenlerden oluşmaktadır ve satın alma niyeti üzerinde pozitif yönlü ve yüksek seviyede bir etkiye sahiptir. Araştırmadaki en yüksek seviyedeki $(0,73)$ katsayı bu iki değişken arasında tespit edilmiştir. Buradan anlaşılacağı üzere, tüketicinin markaya yönelik farkındalığı satın alma eylemine etki etmektedir. Ürün yerleştirme uygulaması sonrası oluşturulan farkındalık akabinde satın alma niyetine dönüşmektedir.

Sonuç olarak bakıldığında bu çalışma, Türkiye'deki televizyon dizileri ve izleyicileri üzerinde yapılan bir çalışmadır. Bu bağlamda, marka farkındalığı ve satın alma niyeti arasındaki ilişki bağlamında televizyon dizilerindeki ürün yerleştirme uygulamalarının önemi ortaya koyulmuştur. Literatürde bu konu üzerine çok az sayıda çalışma yapılmış olması sebebiyle, elde edilen bulguların gelecekte yapılması muhtemel çalışmalara da katkı sağlayacağı düşünülmektedir. Araştırma sorularına bakıldığında, en kayda değer ve önemli bulgu, marka farkındalığının satın alma niyeti üzerinde yüksek seviyeli etkisi olarak görünmektedir. Yapılan analizler sonucu ortaya çıkan bulgular ve bu bulgular ışığında incelenen değişkenler arası ilişkilere yönelik dikkat çeken unsurlar, bu aşamada öneriler şeklinde sunulmuştur.

Öncelikle araştırma sonrası önemli çıkarımlar sağlanmış olsa da bu analiz sonuçlarını toplumun tamamını temsil edecek şekilde değerlendirmek mümkün değildir. Demografik özellikler açısından toplumun genelini daha iyi kapsayacak, tesadüfi örnekleme yapılarak daha homojen bir örneklem ve daha yüksek katılımcıyla yapılacak çalışmalar ile toplumu daha iyi temsil edebilecek niteliğe sahip sonuçlar elde edinilebilir.

Ürün yerleştirme ile ilgili yapılan çalışmalarda, ürün yerleştirmenin satın alma niyetine etkisi ile ilgili analizlerin oldukça sınırlı olduğu görülmektedir. Bu çalışmada ise marka farkındalığının satın alma niyetine etkisi üzerinden ürün yerleştirme uygulamaları incelenmiştir. Gelecekte, satın alma niyeti üzerindeki etkiye yönelik yapılacak çalışmaların sayısı arttırılabilir. Bu çalışmada, sadece Türkiye'deki televizyon izleyicileri ve televizyon dizileri üzerinden bir araştırma yapılmıştır. Teori ve araştırma bölümleri oluşturulurken yapılan literatür taramasında, dünyanın farklı ülkelerinde yapılan benzer çalışmalar incelenmiştir. Bu bağlamda, Türkiye'deki ürün yerleştirme uygulamaları ile yurtdışındaki ürün yerleştirme uygulamalarının, kültürel farklılıklar açısından karşılaştırmalı inceleneceği çalışmalar yapılabilir. Bu çalışmada, ürün yerleştirmenin etkisi incelenirken herhangi bir sektörel ayrıma da gidilmemiştir. Gelecekte, sektörel temele dayanan mukayeseler içeren çalışmalar önerilebilir.

Araştırmada ürün yerleştirme ölçeği üzerinden dört faktör tespit edilmiştir. Model uyum değerleri temel alınarak faktör sayısı bu şekilde belirlenmiştir. Dolayısıyla değişkenler arası değerlendirmeler de bu dört faktör üzerinden yapılmıştır. Gelecekteki çalışmalarda, daha fazla ifade içeren ve daha kapsamlı ölçeklerle faktör sayısı arttırılabilir. Ürün yerleştirme ile başka değişkenler ilişkilendirilebilir ve etki seviyeleri araştırılabilir. 
Çalışmada, marka farkındalığına yönelik sorular ürün yerleştirme ölçeğinin içerisinde yer almıştır. Bu soruların yardımıyla oluşan farkındalık faktörü ayrıştırılarak analizlere devam edilmiştir. Gelecekteki araştırmalarda, marka farkındalığı ayrı bir ölçek üzerinden değerlendirilebilir. Bu şekilde yapıldığı takdirde, marka farkındalığına yönelik alt faktörler ortaya çıkacaktır ve bu da faktörler arası değerlendirmelerin zenginleştirilmesine olanak tanıyacaktır.

$\mathrm{Bu}$ çalışmada ürün yerleştirme uygulamalarının farkındalığa, farkındalığın da satın alma niyetine etkisinin olduğu tespit edilmiştir. Bu sebeple firmalar açısından bakıldığında, markalarına yönelik farkındalığı arttırmak için ürün yerleştirme uygulamalarına ağılık vermeleri tavsiye edilebilir. Son yıllarda Türkiye'deki reklam harcamaları eğilimleri incelendiğinde (Reklamcılar Derneği, Türkiye'de Medya Yatırımları, 2017-2018-2019) TV mecrasının birinci sıradaki yerini koruduğu, dijital platformların da giderek daha etkili bir konuma geldiği görülmektedir. Bu bağlamda, Türkiye'deki firmalar için ürün yerleştirme uygulamalarını öncelikle TV mecrasında yapmaları ve dijital mecralarla bu süreci desteklemeleri faydalı olabilir. Dünya genelinde de bu iki mecra, reklam yatırımlarında en yüksek pazar paylarına sahiptir. Dolayısıyla bu önerinin hem ulusal hem de uluslararası firmalar için geçerli olduğu söylenebilir.

Firmaların, pazarlama iletişimlerini bütünleşik bir şekilde yürütmeleri gerektiği gerçeğinden yola çıkarak; ürün yerleştirme uygulaması yapan firmaların, bu süreci geleneksel pazarlama yöntemleriyle desteklemesi tavsiye edilebilir. Geleneksel reklam veya diğer tutundurma faaliyetleriyle desteklendiği takdirde, yapılan ürün yerleştirme uygulamasının daha faydalı olma ihtimalinin oluşacağını söylemek mümkündür. Ürün yerleştirme uygulamaları, Türkiye için daha önce de söylenildiği gibi oldukça yeni bir pazarlama stratejisidir. Bu sebeple firmalara, kreatif ajanslara ve medya planlama ajanslarına, düzenli olarak dünya genelindeki ürün yerleştirme uygulamalarını incelemeleri ve stratejilerini oluştururkan, bu doğrultuda kararlar vermeleri tavsiye edilebilir.

Bilgilendirme / Acknowledgement:

1- Bu makale Öner Başarır'ın doktora tez çalışmasıyla ilgilidir ve ICES 2019'da sözlü olarak sunulmuştur.

2- Makalede veriler 2018 yılında toplanmış ve yorumlanmıştır.

3- Bu makalede araştırma ve yayın etiğine uyulmuştur.

\section{KAYNAKÇA}

Aaker, D. A. (1991). Managing brand equity: capitalizing on the value of a brand name. New York: The Free Press.

Aaker, D. A. (2009). Marka değeri yönetimi. İstanbul: Mediacat Kitaplar1.

Akgül, D. (2013). Dizi ve filmlerde ürün yerleştirmeye tüketicinin bakışı. 12. Ulusal İşletmecilik Kongresi Bildiri Kitabl, 192, 593-606.

Akın, E. (2008). Bütünleşik pazarlama iletişimi unsuru olarak televizyon reklamları ve tüketicilerin televizyon reklamlarına bakışının tespitine yönelik bir uygulama. Yayımlanmamış doktora tezi, Cumhuriyet Üniversitesi, Sivas.

Alagöz, S. D. ve Güler, B. (2018). Bilgisayar oyunlarında ürün yerleştirmeye yönelik tüketici tutumu ve satın alma niyeti arasındaki ilişki. Kahramanmaraş Sütçü İmam Üniversitesi Sosyal Bilimler Dergisi, 15(2), 479-500.

Altıntaş, D., Kurtuldu, H. S. ve Bilgili, B. (2017). Sinema filmlerindeki ürün yerleştirmeye yönelik izleyici tutumları (Oflu Hoca'nın şifresi 2). Atatürk Üniversitesi Sosyal Bilimler Enstitüsü Dergisi, 21(3), 1007-1023.

Auty, S. ve Lewis, C. (2004). Exploring children's choice: the reminder effect of product placement. Psychology and Marketing, 21(9), 697-713.

Babin, L. A. ve Carder, S. T. (1996). Advertising via the box office: is product placement effective? Journal of Promotion Management, 3(1-2), 31-52. 
Bak, G. ve Eşidir, O. V. (2018). Sinemada ürün yerleştirme: anadolu kartalları örneği. Elektronik Sosyal Bilimler Dergisi, 17(67), 1159-1166.

Balakrishnan, B., Shuaib, A. S., Dousin, O. ve Permarupan, P. Y. (2012). The impact of brand placement and brand recall in movies: empirical evidence from malaysial. International Journal of Management and Marketing Research, 5(2), 39-52.

Baş, A. (2013). Ürün yerleştirme ve TV dizilerinde uygulamaları üzerine bir araştırma. Yayımlanmamış yüksek lisans tezi, Marmara Üniversitesi, İstanbul.

Baş, T. (2005). Anket nasıl hazırlanır, uygulanır ve değerlendirilir? Ankara: Seçkin Yayıncılık.

Başgöze, P. ve Kazancı, Ş. (2014). Ürün yerleştirme ve reklam ilişkin tutumların satın alma eğilimi ve marka imajı üzerine etkileri. Hacettepe Üniversitesi İktisadi ve İdari Bilimler Fakültesi Dergisi, 32(1), 29-54.

Bergeron, J. (2004). Antecedents and consequences of salesperson listening effectiveness in buyerseller relationships. Yayımlanmamış doktora tezi, The John Molson School of Business, Kanada.

Brennan, I., K. M. Dubas ve Babin, L. A. (1999). The influence of product placement type and exposure time on product placement recognition. International Journal of Advertising, 18, 323-337.

Bozkurt, S. (2008). Ürün yerleştirme stratejilerinin marka hatırlama üzerine etkisini belirlemeye yönelik bir araştırma. Yayımlanmamış yüksek lisans tezi, Osmangazi Üniversitesi, Eskişehir.

Bulut, L. (2014). Boyut değiştiren reklamcılık kavramı ve bütünleşik pazarlama iletişimi aracı olarak ürün yerleştirme. Yayımlanmamış yüksek lisans tezi, Gediz Üniversitesi, İzmir.

Chan, F. F. Y. (2012). Product placement and its effectiveness: a systematic review and propositions for future research. Marketing Review, 12(1), 39-60.

Chan, F. F. Y., Lowe B. ve Petrovici, D. (2016). Processing of product placements and brand persuasiveness. Marketing Intelligence \& Planning, 34(3), 355-375.

Cholinski, A. (2012). The effectiveness of product placement: a field quasi-experiment. International Journal of Marketing Studies, 4(5), 14-28.

Cop, R. ve Baş, Y. (2010). Marka farkındalığı ve marka imajı unsurlarına karşı tüketici algıları üzerine bir araştırma. Sosyal Ekonomik Araştırlamalar Dergisi, 10(19), 321-340.

Cowley, E. ve Barron, C. (2008). When product placement goes wrong, the effects of program linking and placement prominence. Journal of Advertising, 37(1), 89-98.

Çakır, A. P. (2011). Sinema filmlerinde ürün yerleştirme yöntemlerinin marka bilinirliğine ve marka hatırlanabilirliğine etkisi. Yayınlanmamış yüksek lisans tezi, Yıldız Teknik Üniversitesi, İstanbul.

Çakır, V. ve Kınıt, E. (2014). Televizyon dizilerinde ürün yerleştirme ve sponsorluğun sonuçları. Global Media Journal: TR Edition, 5(9), 19-47.

Çildir, Ç. (2012). Ürün yerleştirmenin marka hatırlama ve satın alma niyetine etkisini belirlemeye yönelik bir araştırma. Yayımlanmamış yüksek lisans tezi, Osmangazi Üniversitesi, Eskişehir.

D'Astous, A. ve Chartier, F. (2000). A study of factors affecting consumer evaluations and memory of product placements in movies. Journal of Current Issues and Research in Advertising, 22(2), $31-40$.

D'Astous, A. ve Seguin, N. (1999). consumer reactions to product placement strategies in television sponsorship. European Journal of Marketing, 33(9), 896-910.

Delorme, D. E., L. N. Reid ve Zimmer, M. R. (1994). Brands in films: young moviegoers' experiences and interpretations. American Academy of Advertising Conference, Atina. 
Eagle, L. ve Dahl, S. (2018). Product placement in old and new media: examining the evidence for concern. Journal of Business Ethics, 147, 605-618.

Erbaş, S. (2018). Tüketici marka bilgisi: hikaye anlatıcıllı̆̆ ve kolaj tekniği üzerine bir araştırma. Elektronik Sosyal Bilimler Dergisi, 17(67), 1077-1091.

Erdil, T. S. ve Uzun, Y. (2009). Marka olmak. İstanbul: BETA Yayınları.

Eyüboğlu, D. H. (2015). Televizyon dizilerinde ürün yerleştirmenin farkındalık yaratma üzerine etkisi: TV dizilerine yönelik bir araştırma. Yayımlanmamış doktora tezi, Marmara Üniversitesi, İstanbul.

Ferguson, N. S. ve Burkhalter, J. N. (2015). Yo, DJ, That's my brand: an examination of consumer response to brand placements in hip-hop music. Journal of Advertising, 44(1), 47-57.

Gerçek, İ. S. ve İmik Tanyıldızı, N. (2012). Marka farkındalı̆̆ı yaratmada türk sinemasında ürün yerleştirme uygulamaları: anadolu kartalları, kolpaçino bomba ve aşk tesadüfleri sever filmleri üzerine bir araştırma. The Journal of Academic Social Science Studies, 5(8), 1095-1109.

Gupta, P. B. ve Lord, K. R. (1998). Product placement in movies: the effect of prominence and mode on audience recall. Journal of Current Issues and Research in Advertising, 20(1), 47-59.

Gupta, P. B. ve Gould, S. J. (1997). Consumer perceptions of the ethics and acceptability of product placement in movies: product category and individual differences. Journal of Current Issues and Research in Advertising, 19(1), 37-50.

Gürel, E. ve Alem, J. (2014). Ürün yerleştirme. Ankara: Nobel Kitap.

Homer, P. M. (2009). Product placements, the 1mpact of placement type and repetition on attitude. Journal of Advertising, 38(3), 21-31.

Hudson, S. ve Elliott, C. (2013). Measuring the impact of product placement on children using digital brand integration. Journal of Food Products Marketing, 19, 176-200.

Isaksson, J. ve Xavier, S. (2009). Online communities - segments and buying behaviour profiles. Yayımlanmamış yüksek lisans tezi, University of Högskolan I Boras, İsveç.

Jin, C. H. ve Villegas, J. (2007). The effect of the placement of the product in film: consumers emotional responses to humorous stimuli and prior brand evaluation. Journal of Targeting, Measurement and Anlaysis for Marketing, 15(4), 244-255.

Kapferer, J. N. (1992). Strategic brand management: new approaches to creating and evaluating brand equity. New York: Free Press.

Kara, E. (2016). Ürün yerleştirme ve satın alma niyeti üzerindeki etkisi: kullanıldığ ortamlar ve tutundurma yöntemleri açısından mukayeseli analizi. Yayımlanmamış doktora tezi, Atatürk Üniversitesi, Erzurum.

Karrh, J. A. (1994). Effects of brand placement in motion pictures. American Academy of Advertising Conference, Atina.

Karrh, J. A., Frith, K. T. ve Callison, C. (2001). Audience attitudes towards brand (product) placement: singapore and The United States. International Journal of Advertising, 20, 3-24.

Keller, K. L. (2003a). Strategic brand management: building, measuring, and managing brand equity. New Jersey: Prentice Hall.

Keskin, H. D. ve Kurtuldu, H. S. (2017). Tüketicilerin dizi filmlerinden yer alan ürün yerleştirmeye yönelik tutumları üzerine bir araştırma. Gümüşhane Üniversitesi Sosyal Bilimler Enstitüsü Elektronik Dergisi, 8(20), 206-228.

Kozak, M. A. ve Doğan, M. (2014). Dinlenme davranışının müşterinin satın alma niyeti ve satın alma davranışına etkisi: seyahat acentası satış temsilcileri kapsamında bir araştırma. Eskişehir Osmangazi Üniversitesi Sosyal Bilimler Dergisi, 15(2), 57-83. 
Lee, M. ve Faber, R. J. (2007). Effects of product placement in on-line games on brand memory: a perspective of the limited-capacity model of attention. Journal of Advertising, 36(4), 75-90.

Lee, T., Sung, Y. ve Gregorio, F. D. (2011). Cross-cultural challenges in product placement. Marketing Intelligence and Planning, 29(4), 366-384.

Lehu, J. M. ve Bressoud, E. (2008). Effectiveness of brand placement: new insights about viewers. Journal of Business Research, 61, 1083-1090.

Liang, A. R., Hsiao, T. Y. ve Cheng, C. H. (2015). The effects of product placement and television drama types on the consumer responses of college students. Asia Pacific Journal of Tourism Research, 20(11), 1212-1233.

Lin, H. F. ve Chen, C. H. (2013). An intelligent embedded marketing service system based on tv apps: design and 1mplementation through product placement in 1dol dramas. Expert System With Applications, 40, 4127-4136.

Macinnis, D. J., S. Shapiro ve Mani, G. (1999). Enhancing brand awareness through brand symbols. Advances in Consumer Research, 26, 601-608.

Molinillo, S., Japutra, A., Nguyen, B. ve Chen, C. H. (2017). Responsible brands vs active brands? an examination of brand personality on brand awareness, brand trust, and brand loyalty. Marketing Intelligence \& Planning, 35 (2), 166-179.

Naderer, B., Matthes, J., Marquart, F. ve Mayrhofer, M. (2016). Children's attitudinal and behavioral reactions to product placements: investigating the role of placement frequency, placement integration and parental mediation. International Journal of Advertising, 37(2), 236-255.

Nakiboğlu, M. A. B. ve Serin, N. (2016). Ürün yerleștirme uygulamalarının tüketici satın alma niyeti ile ilişkisi hakkında pilot bir araştırma. Niğde Üniversitesi İktisadi ve İdari Bilimler Fakültesi Dergisi, 9(2), 135-151.

Nebenzahl, I. D. ve Secunda, E. (1993). Consumers' attitudes toward product placement in movies. International Journal of Advertising, 12, 1-11.

Russell, C. A. (2002). Investigating the effectiveness of product placements in television shows: the role of modality and plot connection congruence on brand memory and attitude. Journal of Consumer Research, 29(3), 306-318.

Serin, N. (2014). Ürün yerleştirme uygulamalarının tüketici satın alma niyeti ile olan ilişkisinin ortaya çıkartılmasına yönelik pilot bir araştırma. Yayımlanmamış yüksek lisans tezi, Çukurova Üniversitesi, Adana.

Sung, Y. ve De Gregorio, F. (2008). New brand worlds: college student consumer attitudes toward brand placement in films, television shows, songs and video games. Journal of Promotion Management, 14(1-2), 85-101.

Odabaşı, Y. ve Barış, G. (2002). Tüketici davranışı. İstanbul: Mediacat Kitapları.

Ong, B. S. ve Meri, D. (1994). Should product placement in the movies be banned? Journal of Promotion Management, 2(3-4), 159-176.

Öztürk, R. G. (2007). Marka farkındalı̆̆g yaratmada ürün yerleştirmenin etkisi. Yayımlanmamış yüksek lisans tezi, Marmara Üniversitesi, İstanbul.

Redker, C.,B. Gibson ve Zimmerman, I. (2013). Liking of movie genre alters the effectiveness of background poruct placements. Basic and Applied Social Psychology, 35, 249-255.

Taşkın, E. (2003). Satış teknikleri eğitimi. İstanbul: Papatya Yayıncılık.

Tığlı, M. (2004). Bir aktör olarak markalar: ürün yerleştirme. İstanbul: Türkmen Kitabevi.

Toomey, D. A ve Francis, A. L. (2013). Branded product placement and pre-teenaged consumers: influence on brand preference and choice. Young Consumers, 14(2), 180-192. 
Tosun, N. B. (2017). Marka yönetimi. İstanbul: Beta Yayınları.

Tığlı, M., S. Pirtini ve Çelik, C. (2007). Sosyal sorumluluk kampanyalarının genç tüketicilerin marka farkındalığı üzerindeki etkisinin incelenmesine yönelik bir araştırma. TCMÜ, SBE Hakemli Öneri Dergisi, 7(27), 83-93.

Tunçel, H. (2009). Halkla ilişkiler anlayışıyla bütünleşik pazarlama iletişimi. İstanbul Üniversitesi Iletişim Fakültesi Dergisi, 35, 115-136.

Ünal, G. T. (2008). Sinemada ürün yerleştirme 2000-2007 yllları arasında 'academy of motion picture arts and sciences' en iyi film ödülünü almış filmlerin incelenmesi. Yayımlanmamış doktora tezi, Marmara Üniversitesi, İstanbul.

Vollmers, F. (1995). The control of actions by agents. Journal for the Theory of Social Behaviour, 25(2), 175-190.

Wouters, M. ve Pelsmecker, P. D. (2011). Brand placement in scripted and non-scripted Belgian and US programs on Belgian prime time television. Journal of Marketing Communications, 17(5), 299318.

Yang, M., R. Ewoldsen ve David, R. (2007). The effectiveness of brand placements in the movies : levels of placements, explicit and implicit memory, and brand choice behavior. Journal of Communication, 57(3), 469-489.

Yücel, E. ve Çizel, B. (2018). Bilişsel uyumsuzluk teorisi üzerine kavramsal bir inceleme: satın alma perspektifi. Journal of Yasar University, 13(50), 150-163.

Zeren, D. ve Paylar, Ö. Y. (2014). Ürün yerleştirme. Adana: Karahan Kitabevi. 